\title{
Ecological connectivity of seagrasses with mangroves increases the carbon storage of tropical seagrass meadows of an island ecosystem
}

\author{
Amrit Kumar Mishra ( $\square$ akm17@iitbbs.ac.in ) \\ Indian Institue of Technology Bhubaneswar https://orcid.org/0000-0002-9605-3865
}

Deepak Apte

Srusti Conservation Foundation https://orcid.org/0000-0001-5565-4659

Syed Hilal Farooq

Indian Institute of Technology Bhubaneswar https://orcid.org/0000-0003-1769-024X

\section{Research Article}

Keywords: Seagrass, Blue carbon, Tropical islands, Nature-based solution, Ecological connectivity, Mangroves

Posted Date: August 23rd, 2021

DOI: https://doi.org/10.21203/rs.3.rs-839297/v1

License: (c) (i) This work is licensed under a Creative Commons Attribution 4.0 International License. Read Full License 
Ecological connectivity of seagrasses with mangroves increases the carbon storage of tropical seagrass meadows of an island ecosystem

\section{1,2 Amrit Kumar Mishra, ${ }^{3}$ Deepak Apte, ${ }^{1}$ Syed Hillal Farooq}

${ }^{1}$ School of Earth, Ocean and Climate Sciences, Indian Institute of Technology, Bhubaneswar, Argul, Khurda, 752050, India

${ }^{2}$ Department of Marine Conservation, Bombay Natural History Society, Hornbill House, Dr. Salim Ali Chowk, Shaheed Bhagat Singh Road, Opp. Lion Gate, Mumbai, 400001, India

${ }^{3}$ Srusti Conservation Foundation, Flat no-104, Hissa 8, Soba Garden Saffron, C Pune CIT Mahatma Society, Pune, 411038, Maharashtra, India

Corresponding author: akm17@iitbbs.ac.in

\section{Abstract: 289 words/250}

Ecologically connected ecosystems are considered more resilient to climate change mitigation by storing increased amounts of carbon than individual ecosystems. This study quantified the carbon storage capacity of seagrass (Thalassia hemprichii) meadows that are adjacent to mangroves (MG; Rhizophora apiculate) and without mangroves (WMG) at three locations in tropical Andaman and Nicobar Islands (ANI) of India. The sediment organic matter (OM) carbon $\left(\mathrm{C}_{\text {org }}\right)$ content was 2-fold higher at the MG sites than WMG sites of all three locations within the top $10 \mathrm{~cm}$. The $\mathrm{C}_{\text {org }}$ in the total biomass was higher at $\mathrm{MG}$ sites than the biomass at WMG sites. The sediment grain size positively influenced the sediment $\mathrm{OM}$ and $\mathrm{C}_{\text {org }}$ content. The canopy height of $T$. hemprichii showed a better relationship with sediment $\mathrm{OM}$ and $\mathrm{C}_{\text {org }}$ at MG sites. In contrast, the shoot density of $T$. hemprichii showed a better relationship with sediment $\mathrm{OM}$ and $\mathrm{C}_{\text {org }}$ at WMG sites. The total carbon in 144 ha of T. hemprichii meadows of all three MG sites was $11031 \pm 5223 \mathrm{Mg} \mathrm{C}$, whereas the carbon in 148 ha of WMG sites was $4921 \pm 3725 \mathrm{Mg} \mathrm{C}$. These $T$. hemprichii meadows of ANI store around $40487 \pm 19171$ ton of $\mathrm{CO}_{2}$ in the MG sites and $18036 \pm 13672$ ton of $\mathrm{CO}_{2}$ at WMG sites. The social cost of these carbon stored in these T. hemprichii meadows is around US\$34.82 and 1.5 million at the MG and WMG sites, respectively. This study points out the efficiency of seagrass ecosystems of ANI as carbon sinks and the potential of these connected seascapes in increasing the efficiency of seagrass carbon storage. Therefore, this connectivity approach should be further explored to include these connected ecosystems of India as a nature-based solution for climate change mitigation and adaptation plans. 
32 Keywords: Seagrass, Blue carbon, Tropical islands, Nature-based solution, Ecological 33 connectivity, Mangroves

34

35 


\section{Introduction}

Seagrasses are keystone coastal ecosystems that act as natural carbon sinks by sequestering atmospheric $\mathrm{CO}_{2}$ and storing it in their sediments. Together with saltmarsh and mangroves, seagrass ecosystems account for the storage of $50 \%$ of oceanic organic carbon in their sediments (Duarte et al. 2005). Blue carbon refers to the organic carbon (Corg) stored in these ecosystems that has a high potential for offsetting global carbon emissions derived from anthropogenic activities (Macreadie et al. 2019). As long as these ecosystems are conserved or protected from anthropogenic disturbances, the blue carbon stored in their sediments can be stored safely for millenniums (Duarte et al. 2005; Macreadie et al. 2014). However, once destroyed, these ecosystems act as the source of carbon rather than sinks (Salinas et al. 2020; Serrano et al. 2020; Stankovic et al. 2021). As a result, globally, the importance of blue carbon stored in seagrass ecosystems (19.9 Pg of Corg) has gained attention, and their utilization as a nature-based solution for climate change mitigation is gaining momentum (Stankovic et al., 2021; Macreadie et al., 2019; UNEP, 2020). Global research on the blue carbon storage potential of seagrass ecosystems has emphasized the lack of data at local/regional scale studies (Fourqurean et al. 2012a; Howard et al. 2014; Macreadie et al. 2019). Within this framework, India is the least represented in terms of carbon storage in seagrass ecosystems as there is few $(\mathrm{n}=4)$ studies providing carbon storage data of the seagrass ecosystems of India considering its vast seagrass ecosystems (Ghosh et al. 2016; Ganguly et al. 2018; Kaladharan et al. 2020; Stankovic et al. 2021).

Seagrass ecosystems of India consist of 16 seagrass species that covers an area of $517 \mathrm{~km} 2$ along the east and the west coast of India, including the islands of Andaman and Nicobar and Lakshadweep up to a depth limit of $21 \mathrm{~m}$ (Geevarghese et al. 2018; Bayyana et al. 2020). As mentioned above, the carbon storage potential of these seagrass ecosystems is limited to only a few studies and five species, i.e., Halophila ovalis and Halodule uninervis from the Chilika lagoon, Cymodocea serrulata, Syringodium isoetifolium, and Thalassia hemprichii from Palk Bay and Gulf of Mannar region and H. ovalis and T. hemprichii from the Andaman and Nicobar Islands (Ghosh et al. 2016; Ganguly et al. 2018; Kaladharan et al. 2020; Stankovic et al. 2021). Interestingly, Stankovic et al. (2021) observed that an area of 200 hectares of $H$. ovalis and T. hemprichii meadows from the Andaman and Nicobar Islands could reduce around $3 \%$ of the carbon emissions of India, suggesting the massive potential of the seagrass ecosystems of India as a natural carbon sink and its role in offsetting carbon emissions. 
68 Considering the vast area of seagrass ecosystems in India, the present study aims to quantify

69

90 the carbon storage capacity of the Andaman and Nicobar Islands (ANI). The ANI in the Andaman Sea is home to 13 of the 16 seagrass species found in India, covering $29.3 \mathrm{~km} 2$ (Jagtap et al., 2003; Ragavan et al., 2016). Thalassia hemprichii is one of the keystone seagrass species of ANI found in the sandy intertidal habitats and amidst coral rubbles up to a depth of $15 \mathrm{~m}$ (Jagtap et al., 2003). Thalassia hemprichii is also found associated with other seagrass species such as $H$. ovalis and $C$. rotundata or with mangrove ecosystems (Mishra and Mohanraju 2018; Mishra and Apte 2020; Mishra and Kumar 2020). The association of T. hemprichii with mangroves has increased population dynamics, whereas, in areas without mangroves, the population was declining (Mishra and Apte 2020). However, how this connectivity influences the carbon storage capacity of the seagrass meadows of ANI has never been attempted.

Therefore, this study aims to assess the carbon storage capacity of $T$. hemprichii meadows adjacent to mangroves and without mangroves. Similarly, the study will quantify carbon storage of $T$. hemprichii meadows associated with other seagrasses such as $H$. ovalis and $C$. rotundata. We hypothesize that seagrass areas adjacent to mangroves can accumulate and store higher organic carbon than the individual or mixed seagrass meadows. This study aims to evaluate the economic gains of the carbon stored in these seagrass ecosystems and how these carbon sinks can benefit India's carbon reduction plans through Intended Nationally Determined Contribution (INDC) under the Paris Climate Agreement 2015. This study proposes leveraging the monetary values of this blue carbon potential for better conservation and management of seagrass ecosystems in these islands and across India. 


\section{Methods}

\subsection{Study sites}

The Andaman and Nicobar Islands (ANI) are situated in the southeast of India in the Andaman Sea (Fig.1). These islands are rich in seagrass and mangroves due to their tropical settings. These islands are part of the global bioregion model five for seagrasses (Short et al., 2007) and have 13 species of seagrasses that are found in the Indian subcontinent (Mishra and Apte, 2021). The proposed study surveyed three locations of ANI; Saheed Dweep (hereafter called as Neil Island), Swaraj Dweep (hereafter called as Havelock Island) and Burmanallah situated in the southeast side of ANI (Fig.1). This survey was carried in the summer/dry season (FebMarch 2019) of these islands. Sampling was carried out in the coastal ecosystems of the above mentioned three locations where patches of seagrasses (Thalassia hemprichii) and mangroves (Rhizophora apiculate) co-existed. At each location two sites were selected, one where seagrasses are adjacent to mangrove ecosystems (MG) and another without mangroves (WMG). In these study locations a tidal amplitude of $2.45 \mathrm{~m}$, a temperature range of 26.28 to $31.67^{\circ} \mathrm{C}$, and a salinity range 32 to 35 existed. Being an island ecosystem, these study areas exhibited a matrix of ecosystems, where coral reefs (dead or live) were present towards the seaward side, seagrasses in the middle and mangroves towards landward side (Mishra and Mohanraju 2018; Mishra and Apte 2020; Mishra et al. 2021)

\section{Havelock island}

Havelock Island is also situated in the southeast of ANI and north of Neil Island (Fig.1a). The two sites here were 900-1000 m apart and each site was surrounded by dead coral patches. The T. hemprichii population was found in mono-specific patches at both sites. Thallsia hemprichii population was sampled within a depth of $0.5 \mathrm{~m}$ during low tide from meadows adjacent to mangroves (MG;1008 m x $500 \mathrm{~m}$ ) and without mangroves (WMG ; $886 \mathrm{~m}$ x $978 \mathrm{~m}$ ).

\section{Neil Island}

Neil Island is situated in the southeast region of ANI (Fig.1b) The two sites selected here were $1000 \mathrm{~m}$ apart and were separated by dead coral patches. Thalassia hemprichii population was sampled at both MG (250m x $900 \mathrm{~m})$ and WMG (200 m x100 m) sites within a depth of $0.5 \mathrm{~m}$ during low tide. 


\section{Burmanallah}

Burmanallah is situated in the southeast region of ANI (Fig.1c). This location has rocky intertidal beaches and human-made coastal concrete walls. The study sites with mangroves have an outlet that discharges land run-off into the mangrove area. The T. hemprichii meadows within the mangrove area were monospecific. The sites here were $1000 \mathrm{~m}$ apart from each other. T. hemprichii population was sampled within a depth of $0.3 \mathrm{~m}$ during low tide from the MG (800 m x $900 \mathrm{~m})$ and WMG (750 m x $800 \mathrm{~m})$ areas.

\subsection{Seagrass sampling and analysis}

Ten quadrats were collected randomly from a transect of $30 \mathrm{~m}$ perpendicular to the beach at both sites within a depth of $0.5 \mathrm{~m}$ during low tide. We used a quadrat of $20 \mathrm{~cm} \times 20$ $\mathrm{cm}$ and a hand shovel to dig out seagrass samples up to $10 \mathrm{~cm}$ in depth. The density (individual $\mathrm{m}-2)$, biomass $\left(\mathrm{g} \mathrm{DWm}^{-2}\right)$ and canopy height $(\mathrm{cm})$ values were obtained from Mishra and Apte, (2020; See Supplementary Table 2). The separated and dried biomass of $0.2 \mathrm{mg}$ was combusted using a CHNS analyser (Elementar, UNICUBE) to determine the total organic carbon $\left(\mathrm{C}_{\text {org }}\right)$. The biomass $\left(\mathrm{g} \mathrm{DWm}^{-2}\right.$ ) was converted to $\mathrm{Mg} \mathrm{C} \mathrm{DW} \mathrm{ha-1} \mathrm{after} \mathrm{multiplying} \mathrm{by} \mathrm{the} \mathrm{carbon}$ content $(\% \mathrm{C})$ in the above-ground and below-ground biomass.

\subsection{Sediment sampling and analysis}

Sediment cores $(n=10)$ were collected from each quadrat where seagrass was sampled using $5 \mathrm{~cm}$ diameter and $10 \mathrm{~cm}$ long plastic core. It was not possible to collect sediment cores higher than $10 \mathrm{~cm}$ depth because of the habitat structure, which is mostly made of coral reefs or rocks of volcanic origin. The collected sediment cores were stored in plastic zip-lock bags and brought to the laboratory. In the laboratory, the sediment samples were oven-dried at $60^{\circ} \mathrm{C}$ for 72 hours before being sieved for grain size fractions. The sediment samples were homogenized using a disc mill (Retsch, RS 200, USA) after the removal of large stones or twigs.

Then the dry bulk density (DBD $\mathrm{g} / \mathrm{cm}^{3}$ ) of the sediment was calculated as

$$
D B D=\frac{\text { weight of dry soil }}{\text { volume of the core }}
$$

Following the loss on ignition (LOI) method, five grams of homogenized sediment samples was heated to combustion at $450^{\circ} \mathrm{C}$ for 4 hours using a muffle furnace (Heiri et al., 2001). The LOI (\%) was calculated as 
153 Where A is the initial weight of sediment in grams and B is the final weight of sediment after 154 combustion.

155

From the remaining fraction of the homogenized sediment, $1 \mathrm{gm}$ of sediment was acid treated with $10 \% \mathrm{HCl}$ for 24 hours, washed with distilled water and dried again at $60^{\circ} \mathrm{C}$ for 24 hours (Howard et al., 2014). From this acid treated sediment samples $0.2 \mathrm{mg}$ was combusted using CHNS analyser (Elementar, UNICUBE) to determine the total C. A regional relationship between organic matter $(\% \mathrm{LOI})$ and carbon $(\% \mathrm{C})$ content in the sediment was calculated using sediment samples $(\mathrm{n}=18)$ from seagrass meadows with mangroves and without mangroves (Fig.2). The fraction of organic carbon $\left(\% \mathrm{C}_{\mathrm{org}}\right)$ was then calculated using the following relationship:

$\% \operatorname{Corg}=-0.406+(0.512 * \% L O I)$ $\left(\mathrm{MG} ; \mathrm{R}^{2}=0.94\right)$

$\% \operatorname{Corg}=-1.117+(0.496 * \% L O I)$ ..(WMG; $\left.\mathrm{R}^{2}=0.89\right)$

The total carbon $\left(\mathrm{Mg} \mathrm{ha}^{-1}\right)$ was calculated by adding the total carbon in the sediment and the seagrass biomass (Howard et al., 2014). The total areas of all seagrass meadows included in this study (Table1) were multiplied by the quantified carbon present in the seagrass biomass $\left(\mathrm{Mg} \mathrm{Cha}^{-1}\right)$ and in the sediment $\left(\mathrm{Mg} \mathrm{Cha}^{-1}\right)$ to calculate the total carbon stored in these seagrass meadows of three locations of ANI. The carbon dioxide $\left(\mathrm{CO}_{2}\right)$ equivalent emission/storage per hectare $\left(\mathrm{Mg} \mathrm{CO}_{2} \mathrm{ha}^{-1}\right)$ was calculated by multiplying the $\mathrm{CO}_{2}$ conversion factor (3.67) by the mean carbon stock of the seagrass ecosystem (Howard et al., 2014).

\subsection{Valuation of carbon sequestration and storage}

The social cost of carbon (SCC) represents the economic cost associated with climate chage related damage (or benefit) due to emission of one ton of $\mathrm{CO}_{2}$ or its equivalent (Nordhaus 2017; Ricke et al. 2018). We used the regional approach to estimate SCC, than the global approach, as country level (regional) estimates allow better understanding of regional impacts and are important for better adaptation and compensation measures (Ricke et al., 2018). We used the recent estimate of SCC for India, which is US\$86 per ton $\mathrm{CO}_{2}$ (Ricke et al., 2018). Recent US\$ to Indian Rupees (INR) conversion was used to estimate the price of $\mathrm{CO}_{2}$ in rupees. 
182 Pearson Correlation was used to test the effects of plant height and density in trapping higher 183 or lower organic matter/carbon content in the meadows. Similarly, a correlation between 184 sediment grain size and organic matter/organic carbon was tested to check the influence of 185 sediment grain size in storing higher or lower organic matter/carbon. Two-way ANOVA was 186 used to test the significant differences between T. hemprichii density and biomass estimates 187 with sites (with mangroves (MG) and without mangroves (WMG)) and locations of ANI (Neil, 188 Havelock, and Burmanallah) as fixed factors. All data was pre-checked for normality and 189 homogeneity of variance. When variances were not homogenous, data were $\ln (\mathrm{x}+1)$ 190 transformed. When there were significant effects, the Holm-Sidak test was performed for a 191 posteriori comparison among factor levels. All statistical tests were conducted at a significance 192 level of $p<0.05$ (Sokal and Rohlf, 2012), and data are presented as mean and standard error 193 (S.E.). Sigmaplot (ver. 11.01.102) software was used for all statistical analyses. 


\section{Results}

The sediment dry bulk density of $T$. hemprichii meadows was significantly different $(\mathrm{p}<0.001)$ between the three locations than among the MG and WMG sites of each location (Table 1). In general, the dry bulk density was 1-fold higher among the $T$. hemprichii meadows associated without mangroves $\left(0.84 \pm 0.13 \mathrm{~g} \mathrm{~cm}^{-3}\right)$ than the meadows with mangroves $\left(0.75 \pm 0.23 \mathrm{~g} \mathrm{~cm}^{-3}\right)$ (Table 1). The mean organic matter $(52.55 \pm 16.49 \% \mathrm{DW})$ and $\mathrm{C}_{\text {org }}(26.51 \pm 8.44 \% \mathrm{DW})$ in the sediment of T. hemprichii meadows associated with MG sites was 1.3-fold and 1.4-fold higher than the meadows of WMG areas (Table 1). The relationship between the sediment organic matter and $\mathrm{C}_{\text {org }}$ were significant for both $\mathrm{MG}\left(\mathrm{R}^{2}=0.94\right)$ and $\mathrm{WMG}\left(\mathrm{R}^{2}=0.89\right)$ locations, with a better relationship at $T$. hemprichii meadows within the MG than WMG areas at all three locations (Fig.2).

The mean AB-and BG-biomass were significant and different between the locations and sites (Fig.3). The AB-biomass (1.99 $\left.\pm 0.48 \mathrm{Mg} \mathrm{DW} \mathrm{ha}^{-1}\right)$ of T. hemprichii at the MG sites was 2.4fold higher than the biomass at WMG sites $\left(0.82 \pm 0.31 \mathrm{Mg} \mathrm{DW} \mathrm{ha}^{-1}\right)$. The BG-biomass of $T$. hemprichii followed a similar pattern and was 1.5-fold higher at MG (3.94 $\pm 0.89 \mathrm{Mg} \mathrm{DW}^{-}{ }^{-}$ $\left.{ }^{1}\right)$ than WMG $\left(2.55 \pm 0.76 \mathrm{Mg} \mathrm{DW} \mathrm{ha}^{-1}\right)$ sites. The total biomass ( $\mathrm{AB}+\mathrm{BG}$ biomass) was higher between the three locations at Neil Island MG sites than at Havelock and Burmanallah locations (Fig.3). In general, the carbon content in AB-biomass (leaves) of T. hemprichii was higher than the BG-biomass (rhizomes + roots), which resulted in higher Corg in the AB-biomass than the BG-biomass (Table 1). The carbon content in AB-biomass was 1.4-fold higher at the MG sites $(49.12 \pm 17.12 \% \mathrm{DW})$ than at the WMG sites $(35.1 \pm 5.32 \% \mathrm{DW})$. Similarly, the carbon content

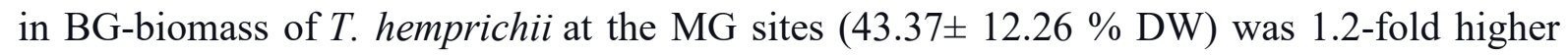
than WMG sites $(34.86 \pm 5.25 \mathrm{C} \% \mathrm{DW})$ (Table 1). These higher carbon content resulted in higher $\mathrm{C}_{\text {org }}$ in AB-biomass than BG-biomass at MG sites than WMG sites (Fig.1). The $\mathrm{C}_{\text {org }}$ in AB-biomass of T. hemprichii at the MG sites $\left(90.78 \pm 70.7 \mathrm{Mg} \mathrm{C} \mathrm{DW} \mathrm{ha}^{-1}\right)$ was 3.2-fold higher than WMG sites $\left(27.74 \pm 9.01 \mathrm{Mg} \mathrm{C} \mathrm{DW} \mathrm{ha}^{-1}\right)$. In contrast, the $\mathrm{C}_{\text {org }}$ in BG-biomass of $T$. hemprichii at the MG sites (141.89 $\left.\pm 83.7 \mathrm{Mg} \mathrm{C} \mathrm{DW} \mathrm{ha}^{-1}\right)$ was 1.8-fold higher than WMG sites (78.23 $\pm 45.38 \mathrm{Mg} \mathrm{C} \mathrm{DW} \mathrm{ha}^{-1}$ ) (Table 1). Between the three locations, following the total biomass patterns, the $\mathrm{C}_{\text {org }}$ in $T$. hemprichii meadows was higher in the total biomass of the Neil Island than the other two locations (Fig.1).

In general, the carbon content in the sediment was lower than that of carbon in the biomass of T. hemprichii meadows at both MG and WMG sites (Table 1). The carbon content in the sediment of $T$. hemprichii meadows at the MG sites $(26.51 \pm 8.44 \% \mathrm{DW})$ was 1.4 -fold higher 
than the meadows at WMG sites $(18.49 \pm 6.63 \% \mathrm{DW})$. Among the three locations, the sediments of $T$. hemprichii meadows at the Burmanallah MG site was recorded with the highest carbon content in the sediment, followed by the Havelock MG site (See Supplementary Table 1). A similar pattern was observed for the carbon content in the sediment of $T$. hemprichii meadows at the WMG sites.

Higher carbon content in the sediment at MG sites resulted in higher Corg in $T$. hemprichii meadows associated with MG sites than WMG sites (Table 1). The mean Corg in the sediment of $T$. hemprichii meadows at the MG sites $\left(21.87 \pm 11.53 \mathrm{Mg} \mathrm{C} \mathrm{ha}^{-1}\right)$ was 1.4 -fold higher than the WMG sites (15.62 $\pm 6.50 \mathrm{Mg} \mathrm{C}^{-1}$ ) (Fig.4). Interestingly owing to the low sediment dry bulk density of T. hemprichii meadows at the MG site of Neil Island, the sediment Corg was 1.2-fold lower at the MG site than the WMG site (Fig.4a). However, among the three locations, the Corg in the sediment of T. hemprichii meadows at Burmanallah was the highest, followed by the MG site of Havelock (Fig.4a). The total Corg in the sediment between the three locations was higher at MG sites $(1265.35 \pm 1010 \mathrm{Mg} \mathrm{C})$ than at the WMG sites $(839.07 \pm$ 641.05 Mg C) (Table 1). Between the three locations, the highest total Corg in the sediment was recorded in the T. hemprichii meadows of Burmanallah location, followed by Havelock and Neil Islands (See Supplementary Table 1).

The carbon storage as $\mathrm{CO}_{2}$ equivalent in the T. hemprichii meadows ranged between 147$10400 \mathrm{Mg} \mathrm{CO}_{2}$ at the MG sites and between 28-6529 $\mathrm{Mg} \mathrm{CO}_{2}$ at the WMG sites (Fig.4b). The $\mathrm{CO}_{2}$ equivalent storage followed the same pattern as total $\mathrm{C}_{\text {org }}$ in the sediment. The average price of this carbon is around 0.39 million US\$ for MG sites and 0.26 million US\$ for WMG sites, while the price of this carbon in Indian Rupees (INR) was 29.69 and 19.69 million for MG and WMG sites, respectively. The total carbon in the ecosystem (carbon in total biomass+ sediment) was 2-fold higher at the MG sites $\left(272.54 \pm 164 \mathrm{Mg} \mathrm{C} \mathrm{ha}^{-1}\right)$ compared to the WMG sites $(128.79 \pm 55.89 \mathrm{Mg} \mathrm{C}$ ha-1) (Table 1). Due to the higher total biomass of $T$. hemprichii meadows of Neil Island, the total carbon in the ecosystem was higher at the Neil Island MG site, followed by Havelock and Burmanallah locations (Fig.4c). The total $\mathrm{C}_{\text {org }}$ for the studied area of $T$. hemprichii meadows was 2.2-fold higher at MG sites $(11031 \pm 5223 \mathrm{Mg}$ C) than WMG sites $(4921 \pm 3725 \mathrm{Mg} \mathrm{C})$. Similarly, the mean carbon equivalent of $\mathrm{CO}_{2}$ storage in the entire ecosystem was higher at MG sites $\left(40487 \pm 19171 \mathrm{Mg} \mathrm{CO}_{2}\right)$ than at WMG sites $\left(18036 \pm 13672 \mathrm{Mg} \mathrm{CO}_{2}\right)$ (Fig.4d). Among the locations, the MG sites of Neil Island stored the highest $\mathrm{CO}_{2}$ equivalent, followed by Havelock and Burmanallah (Fig.4). The mean price of the carbon stored in the entire ecosystem of $T$. hemprichii meadows of ANI at MG sites 
266 (34.82 \pm 16.48 million US\$) and WMG sites $(1.55 \pm 1.17$ million US\$). The price in INR for 267 MG sites is 2589 million INR, and that of WMG sites is 115.52 million INR (Table 1).

268 The relationship between sediment silt content with organic matter/Corg was significant for 269 both MG and WMG sites, with higher significance at MG sites (Fig.5). The morphometrics of $270 T$. hemprichii, such as canopy height and shoot density, positively influenced the sediment 271 organic matter/ $\mathrm{C}_{\text {org }}$ content at both $\mathrm{MG}$ and WMG sites (Fig.6). The canopy height of $T$. 272 hemprichii showed a better relationship with sediment organic matter/ $\mathrm{C}_{\text {org }}$ at $\mathrm{MG}$ sites of all 273 three locations (Fig.6a \& b). In contrast, the shoot density of T. hemprichii showed better 274 relationships at WMG sites of all three locations (Fig.6c \& d). 


\section{Discussion}

Ecological connectivity between seagrass and mangroves is a multifaceted process and plays an important role in the ecological functioning of coastal ecosystems (Berkström et al. 2020; Mishra and Apte 2020; Carlson et al. 2021). This connectivity between seagrass and mangrove ecosystems positively influences the carbon storage capacity in the seagrass ecosystems (Juma et al. 2020; Asplund et al. 2021). The present study quantified the carbon storage in ecologically connected seagrass and mangrove ecosystems in a tropical island (ANI) ecosystem and observed that seagrass meadows adjacent to mangrove ecosystems store a higher amount of carbon in their sediment and biomass compared to seagrass ecosystems without mangroves. This influence of ecological connectivity with mangroves on seagrass ( $T$. hemprichii) population dynamics has been previously studied in ANI, India (Mishra and Apte, 2020). However, to our knowledge, this is the first time the influence of mangroves on seagrass carbon storage has been quantified in ANI and India.

\subsection{Carbon stored in the sediment}

Sediment grain size $(<63 \mu \mathrm{m})$ plays an important role in carbon accumulation and storage in seagrass meadows across biogeographical regions (Mazarrasa et al. 2018; Ricart et al. 2020; Potouroglou et al. 2021; Santos et al. 2021). The dry bulk density observed in our study was within the global range of sediment density (1.03 $\pm 0.02 \mathrm{~g} \mathrm{DW} \mathrm{cm} 3)$ observed for seagrass meadows ((Fourqurean et al. 2012b). In the present study, the fine fraction of sediment (mostly silt) distribution in T. hemprichii meadows associated with mangroves was low at the Neil and Havelock islands. This is because the $T$. hemprichii meadows were growing on sandy substrates with coral rubbles, and the Rhizophora apiculate mangrove ecosystems of both the islands do not receive land-based run-off, whereas the T. hemprichii meadows at Burmanallah received such input (Mishra and Apte, 2020; Nobi et al., 2010; Savurirajan et al., 2018). Mangrove ecosystems of these islands play an essential role in out-welling nutrients to the surrounding ecosystems, which includes organic matter and organic carbon content (Jha et al. 2013, 2015; Sahu et al. 2013; Mishra and Kumar 2020).

Seagrass meadows are efficient in trapping sediment and organic matter from the water column that comes their way from the mangrove ecosystem through daily receding tides (Miyajima et al. 2017). Seagrasses utilize the height of their leaves (canopy height) and dense rhizome network to trap the inflowing particles and organic matter (Samper-Villarreal et al. 2016; Potouroglou et al. 2017; Barcelona et al. 2021). This mechanism is evident in our study, as there is a better correlation between the canopy height of $T$. hemprichii with organic matter 
content at MG sites (Fig.6). Similar correlations are observed for shoot density and organic matter content in MG sites (Fig.6). However, it is essential to notice here that the $T$. hemprichii meadows at the WMG sites exhibited better correlations of organic matter with shoot density than the MG sites. This is probably because the WMG sites in our study locations are exposed to high wave dynamics that make them prone to leaf breakage resulting in reduced canopy height (Fig.7b, Mishra and Apte, 2020). As a result, the plant invests in better below ground structures to withstand the wave dynamics, resulting in higher organic matter trapping. Secondly, the ecosystem matrix of Neil and Havelock islands are such that the $T$. hemprichii meadows at WMG sites are exposed to high intertidal temperatures resulting in leaf damage and leaf reddening (Fig.7a). Similar mechanisms of hydrodynamic setting and its influence on seagrass ecosystems have been observed elsewhere (Beaufort et al., 1998; Saenger \& Funge-Smith, 2012). Furthermore, the influence of local hydrodynamic settings, sediment grain size, canopy height and shoot density having a positive effect on various seagrass species and connected mangrove seascapes have also been observed for T. hemprichii, Cymodocea rotundata, Enhalus acoroides and Thalassodendron ciliatum from the coast of Madagascar (Asplund et al., 2021) and Gazi Bay of Kenya on C. rotundata, C. serrulata, E. acoroides, T. ciliatum (Juma et al., 2020).

The sediment $\mathrm{C}_{\text {org }}$ in our present study is significantly higher ( $\sim-13$ times) than other studies of seagrass meadows from the east coast of India (Ghosh et al. 2016; Ganguly et al. 2017a; Kaladharan et al. 2020, 2021). The sediment $\mathrm{C}_{\text {org }}$ in our study is also higher than the global average $(5.7 \pm 0.3 \% \mathrm{C} \mathrm{DW})$ but was within the range $(0-100 \% \mathrm{C} \mathrm{DW})$ reported for various seagrass ecosystems (Fourqurean et al., 2012). However, this global study lacked data points for India, including ANI. Higher $\mathrm{C}_{\text {org }}$ in the sediment of ANI could be possible for two reasons, 1) the previous authors have mainly studied seagrass ecosystems that are not connected to mangroves. As a result, the sediment organic carbon is not influenced by mangrove based outwelling and 2) being an island ecosystem and oligotrophic, the T. hemprichii meadows have adapted to store a higher amount of carbon within their sediment. However, other than mangroves, seaweed and macroalgal communities associated with dead and live corals may have contributed to the sediment organic carbon fraction (Ricart et al. 2015; Liu et al. 2020; Mazarrasa et al. 2021). Higher sediment $C_{\text {org }}$ than the seagrass meadows of the mainland coast of India has also been observed by Sachithanandanam et al. (2020) at Burmanallah and Havelock Island of ANI previously. This indicates that the seagrass ecosystem of ANI stores a higher amount of Corg in their sediment, and the presence or absence of mangroves directly influences this organic carbon storage. In general, it is thought that the seagrass ecosystems 
contribute $98 \%$ of the autochthonous $\mathrm{C}_{\text {org }}$ in the sediment (Lavery et al. 2013; Serrano et al. 2018). However, $50 \%$ of this autochthonous $\mathrm{C}_{\text {org }}$ is buried in the seagrass meadows, and the rest is transferred to surrounding ecosystems (Duarte and Krause-Jensen, 2017). However, our results suggest that in tropical island ecosystems and adjacent to mangroves, this contribution and storage can change, as seagrass can accumulate and develop organic-rich soil consisting of autochthonous and allochthonous carbon (Kennedy et al. 2010; Duarte et al. 2013) if its remains sheltered and less disturbed compared to disturbed conditions at WMG sites. A similar influence of mangroves on seagrass sediment $\mathrm{C}_{\text {org }}$ has been observed for $T$. hemprichii from the Western Indian Ocean region (Asplund et al., 2021).

\subsection{Carbon stored in Total Biomass}

The mean AB-biomass and BG-biomass at the MG and WMG sites of ANI were within the range limit (AB;2.15 and $\mathrm{BG} ; 5.08 \mathrm{Mg} \mathrm{DW} \mathrm{ha}^{-1}$ ) for the global seagrass ecosystem (Fourqurean et al., 2012). The carbon stored in seagrass BG-biomass is generally 2 -fold higher than the ABbiomass (Fourqurean et al., 2012), and our results showed a similar pattern (See Supplementary Table 2). The differences in $\mathrm{C}_{\text {org }}$ in AB-and BG-biomass was more evident at the WMG sites (2.8-fold) than at the MG sites (1.5-fold) because the AB-biomass of the WMG sites were more prone to breakage and loss than at MG sites. As compensation for this breakage of leaves, $T$. hemprichii involves most of its stored energy in leaf growth, vertical rhizome growth and below-ground roots (Mishra and Apte, 2020). This resulted in an almost 3-fold higher $\mathrm{C}_{\text {org }}$ in the BG-biomass of T. hemprichii at the WMG sites than the AB-biomass. This higher biomass at MG sites of the three locations enhanced the capacity of $T$. hemprichii meadows to store higher autochthonous $\mathrm{C}_{\text {org }}$ in their meadows. The meadow size also facilitated this higher carbon storage, the density, rhizomes, roots, seagrass necromass and dissolved organic carbon are that are higher at MG than WMG sites of the three locations, that contribute significantly to the primary production of these meadows (Mishra and Apte, 2020; Mishra and Kumar, 2020), resulting in higher carbon in the biomass. Higher productivity leading to higher carbon storage in the biomass has been observed for T. hemprichii mixed meadows at the Palk Bay and Gulf of Mannar region of Tamil Nadu in India (Ganguly et al., 2017; Singh et al., 2015).

\subsection{Total carbon in the seagrass ecosystem}

The total carbon stored in the seagrass ecosystem (sediment + biomass) at the MG and WMG sites showed a high standard deviation (Table 1) because of differences in habitat configuration of each study location. Secondly, the total meadow size (in hectares) for each of the MG and 
WMG sites at all three locations were different. For example, the total biomass of $T$. hemprichii meadows was higher at the MG site of Neil Island than the other two locations, but due to the small area, the total carbon in the ecosystem was on the lower side (Fig.4). Similarly, with a smaller size at the WMG site, the carbon in the ecosystem was the lowest at Neil Island. Consequently, even though the biomass of T. hemprichii at Burmanallah MG and WMG sites were lower than the other two locations, due to the higher meadow area, the meadows of $T$. hemprichii had the second-highest carbon in the entire ecosystem (Fig.4). This suggests that seagrass meadow size plays an important role in determining the total carbon storage in the ecosystem. A similar impact of meadow size affecting seagrass carbon storage has been observed for seagrass ecosystems of India at Chilika lake of Odisha, Pulicat lake, Gulf of Mannar and Palk Bay of Tamil Naidu (Ghosh et al. 2016; Ganguly et al. 2017a; Kaladharan et al. 2020, 2021).

Previous studies have shown that the total carbon in the seagrass meadows of ANI (184.24 \pm 23.84 $\mathrm{Mg} \mathrm{C} \mathrm{ha}^{-1}$ ) is higher than in other southeast Asian countries (Stankovic et al. 2021). Our findings agree with the previous studies and show that seagrass meadows of ANI have $66 \%$ higher carbon storage capacity at MG sites $\left(272.54 \pm 164 \mathrm{Mg} \mathrm{C} \mathrm{ha}^{-1}\right)$ and low at WMG sites $\left(128.79 \pm 55.89 \mathrm{Mg} \mathrm{C} \mathrm{ha}^{-1}\right)$. These differences in our study from Stankovic et al. (2021) is probably because the authors derived the total carbon in the ecosystem through a model-based approach, whereas in our study, we have used the traditional methods of quantification recommended for blue carbon research (Howard et al., 2014). The total carbon stock in the $T$. hemprichii meadows at the MG sites (144ha; $11031 \pm 5223 \mathrm{Mg} \mathrm{C}$ ) was 2-fold higher than the WMG sites (148 ha; $4921 \pm 3725 \mathrm{Mg} \mathrm{C}$ ) of ANI. This indicates that T. hemprichii meadows associated with mangroves can store a higher amount of carbon in the ecosystem than individual seagrass ecosystems. These islands of ANI are oligotrophic; as a result, even though the total meadow size at WMG sites were higher, it did not result in higher carbon storage in the ecosystem.

Consequently, with a small meadow size, the MG sites were able to accumulate higher carbon stocks. Because at the MG sites, there is a flow of nutrients and organic matter from the mangrove ecosystem (Mishra and Kumar, 2020; Jha et al., 2015; Sahu et al., 2013) that helps the $T$. hemprichii meadows in meeting their nutrient demands and increasing productivity (Mishra and Apte, 2020). The total carbon stock in our studies is limited to the upper $10 \mathrm{~cm}$ of the sediment depth as dead corals made it challenging to collect increased depth cores. So, the standard extrapolation of sediment depth to $1 \mathrm{~m}$ was avoided. Similarly, from the seagrass meadow perspective, we estimated the carbon stock in a total of 292 ha for both MG and WMG 
sites and have avoided the extrapolation to the total seagrass area of ANI. Avoiding the extrapolation was necessary because, in India, previous seagrass carbons storage research has measured carbon storage in a single species and have extrapolated that data to the total seagrass coverage, which have mixed species of seagrass (Kaladharan et al. 2020, 2021; Ghosh et al. 2018). This has resulted in biased carbon storage values because seagrass carbon storage capacity is species-specific, and the local abiotic factors such as hydrodynamics, land run-off, anthropogenic pollution and habitat disturbances play an important role in determining this capacity (Howard et al., 2014; Duarte and Krause-Jensen, 2017; Macreadie et al., 2019). Based on the International Panel for Climate Change (IPCC, 2014) Tier 1 assessment, the MG sites can prevent the emission of $40487 \mathrm{Mg} \mathrm{CO}_{2}$, while the WMG sites can prevent $18036 \mathrm{Mg} \mathrm{CO}_{2}$ (Howard et al., 2014). Based on the amount of carbon stored in the MG and WMG site of ANI, the price of this $\mathrm{CO}_{2}$ storage is around 34.82 million US\$ for MG sites and 1.55 million US\$ for WMG sites. However, our values differ from the previously reported pricing values of Stankovic et al. (2021) for ANI because the previous authors use carbon pricing for ANI based on (Nurdianto and Resosudarmo, 2016) for ASEAN countries, where the price of one ton of $\mathrm{CO}_{2}$ was priced at US\$10. Whereas we used the recent price for one ton of $\mathrm{CO}_{2}$ for India by Ricke et al. (2018) at US\$86. However, ANI is part of India and not ASEAN countries, which seemed appropriate for estimating the social cost of carbon using the recent price by Ricke et al. (2018).

4.4. Contribution of seagrass ecosystems for India's Intended Nationally Determined Carbon (INDC) Plans

In its INDC commitments under Paris Climate Agreement (UNFCC, 2015), India has pledged to reduce $33-35 \%$ of its carbon emissions by 2030 . The foundation in achieving this target is laid in the National Environmental Policy, 2006, which promotes sustainable development while protecting and conserving the various ecosystems. The National Action Plan on Climate Change (NAPCC) further sustains the idea of ecosystem management through national missions, which outlines priorities for climate change mitigation and adaptation measures. The present studied seagrass ecosystems of ANI can store $0.17 \mathrm{Mg}$ ton $(0.007 \%)$ of the total $\mathrm{CO}_{2}$ emissions of India (2300 Mg ton; Karstensen et al., 2020). However, this fraction is very small considering the huge emissions of India. However, the total seagrass area of ANI was not considered in this study which can reflect different carbon storage scenarios.

Furthermore, the blue carbon storage potential of seagrass ecosystems of India needs more detailed studies considering species-specific carbon storage potential. Secondly, seagrass ecosystems of India are missing in any of the climate change mitigation plans (Koshy et al. 
446 2018; Ramesh et al. 2018), whereas mangroves are included. However, through this carbon

447 storage study of ecologically connected seagrass and mangrove ecosystems of ANI, this study

448 emphasizes on the importance of seagrass ecosystems. Secondly, as these seagrass ecosystems

449 are adjacent to mangrove ecosystems of ANI, these ecosystems can be considered along the

450 Mangroves for the Future (MFF) and Island Protection Zones (IPZ) programs of the NAPCC

451 for initiating conservation and management practices for seagrass ecosystems of India that are

452 under decline from various anthropogenic activities (Mishra and Apte, 2020; Mishra et al.,

453 2021a, 2021b). Loss of seagrass ecosystems of India will make these ecosystems as source of

454 carbon emission than storehouse and can release various other greenhouse gases (Banerjee et

455 al., 2018).

\section{5.Conclusion}

457 Seascape connectivity across blue carbon habitats results in higher carbon storage than 458 individual ecosystems (Huxham et al. 2018; Macreadie et al. 2019) and our results agree 459 showcase this increased carbon storage in seagrass meadows associated with mangroves. This 460 present study adds new data and knowledge to the growing importance of connected 461 ecosystems across coastal seascapes and their role in increased carbon storage in the ecosystem.

462 To our knowledge, this is for the first-time carbon storage of connected ecosystems is reported 463 from India. This study observed a 2-fold increase in carbon storage capacity of seagrass 464 meadows associated with mangroves than without mangroves, probably due to organic matter 465 and carbon input from the mangrove ecosystems. The positive influence of this cross-habitat 466 connectivity on blue carbon storage potential within the coastal seascape of ANI and other parts 467 of India needs further exploration as nature-based solutions for climate change mitigation plans 468 of India. This ecosystem service of seagrasses of India needs to be integrated with NAPCC for 469 better management of seagrass ecosystems of India (UNEP, 2020). 


\section{Acknowledgment}

473 A part of this project received funding from the Science and Engineering Board, Government 474 of India, file number PDF/2020/000540. Thanks to Prasannajit Acharya for his help in 475 laboratory work. Thanks to Dr. Manish Kumar for his help in providing laboratory support. IIT 476 Bhubaneswar is thanked for providing laboratory support. 


\section{References}

A Nurdianto D, P. Resosudarmo B (2016) The Economy-wide Impact of a Uniform Carbon Tax in ASEAN. Southeast Asian Economies 33:1-22. https://doi.org/10.1355/ae33-1a

Asplund ME, Dahl M, Ismail RO, et al (2021) Dynamics and fate of blue carbon in a mangrove-seagrass seascape: influence of landscape configuration and land-use change. Landscape Ecology 36:1489-1509. https://doi.org/10.1007/s10980-021-01216-8

Banerjee, K., Paneerselvam, A., Ramachandran, P., Ganguly, D., Singh, G., Ramesh, R., 2018. Seagrass and macrophyte mediated $\mathrm{CO} 2$ and $\mathrm{CH} 4$ dynamics in shallow coastal waters. PLoS One 13, 1-22. https://doi.org/10.1371/journal.pone.0203922

Barcelona A, Oldham C, Colomer J, et al (2021) Particle capture by seagrass canopies under an oscillatory flow. Coastal Engineering 103972. https://doi.org/10.1016/j.coastaleng.2021.103972

Bayyana S, Pawar S, Gole S, et al (2020) Detection and mapping of seagrass meadows at Ritchie's archipelago using Sentinel 2A satellite imagery. Current Science 118:12751282. https://doi.org/10.18520/cs/v118/i8/1275-1282

Beaufort LN, Carolina N, Fonseca MS, et al (1998) Influence of Physical Setting on Seagrass Influence of physical setting on seagrass landscapes

Berkström C, Eggertsen L, Goodell W, et al (2020) Thresholds in seascape connectivity: the spatial arrangement of nursery habitats structure fish communities on nearby reefs. Ecography. https://doi.org/10.1111/ecog.04868

Carlson RR, Evans LJ, Foo SA, et al (2021) Synergistic benefits of conserving land-sea ecosystems. Global Ecology and Conservation 28:e01684. https://doi.org/10.1016/j.gecco.2021.e01684

Duarte, C M Middelburg J J, Caraco N (2005) Major role of marine vegetation on the oceanic carbon cycle. Biogeosciences 1:1-8

Duarte CM, Kennedy H, Marbà N, Hendriks I (2013) Assessing the capacity of seagrass meadows for carbon burial: Current limitations and future strategies. Ocean and Coastal Management 83:32-38. https://doi.org/10.1016/j.ocecoaman.2011.09.001 
505

506

507

508

509

510

511

512

513

514

515

516

517

Fourqurean JW, Duarte CM, Kennedy H, et al (2012a) Seagrass ecosystems as a globally significant carbon stock. Nature Geoscience 5:505-509. https://doi.org/10.1038/ngeo1477

Fourqurean JW, Duarte CM, Kennedy H, et al (2012b) Seagrass ecosystems as a globally significant carbon stock. Nature Geoscience 5:505-509. https://doi.org/10.1038/ngeo1477

Ganguly D, Singh G, Purvaja R, et al (2018) Valuing the carbon sequestration regulation service by seagrass ecosystems of Palk Bay and Chilika, India. Ocean and Coastal Management 159:26-33. https://doi.org/10.1016/j.ocecoaman.2017.11.009

Ganguly D, Singh G, Purvaja R, et al (2017a) Valuing the carbon sequestration regulation service by seagrass ecosystems of Palk Bay and Chilika, India. Ocean and Coastal Management 159:26-33. https://doi.org/10.1016/j.ocecoaman.2017.11.009

Ganguly D, Singh G, Ramachandran P, et al (2017b) Seagrass metabolism and carbon dynamics in a tropical coastal embayment. Ambio 46:667-679. https://doi.org/10.1007/s13280-017-0916-8

Geevarghese GA, Akhil B, Magesh G, et al (2018) A comprehensive geospatial assessment of seagrass distribution in India. Ocean and Coastal Management 159:16-25. https://doi.org/10.1016/j.ocecoaman.2017.10.032

Ghosh R, Trivedi S, Pramanick P, et al (2016) Seagrass : A Store House of Carbon. Journal of Energy, Environment \& Carbon Credits 5:23-29

Howard J, Hoyt S, Isensee K, et al (2014) Coastal Blue Carbon. National Wetlands Newsletter 36:5-7

Jagtap TG, Komarpant DS, Rodrigues RS (2003) Status of a seagrass ecosystem: An ecologically sensitive wetland habitat from India. Wetlands 23:161-170. https://doi.org/10.1672/0277-5212(2003)023[0161:SOASEA]2.0.CO;2

Jha DK, Prashanthi Devi M, Vinithkumar N v., et al (2013) Comparative Investigation of Water Quality Parameters of Aerial \&amp; Rangat Bay, Andaman Islands Using In-Situ Measurements and Spatial Modelling Techniques. Water Quality, Exposure and Health 5:57-67. https://doi.org/10.1007/s12403-013-0086-2 
Jha DK, Vinithkumar NV, Sahu BK, et al (2015) Multivariate and geo-spatial approach for seawater quality of Chidiyatappu Bay, south Andaman Islands, India. Marine Pollution Bulletin 96:463-470. https://doi.org/10.1016/j.marpolbul.2015.05.004

Juma GA, Magana AM, Michael GN, Kairo JG (2020) Variation in Seagrass Carbon Stocks Between Tropical Estuarine and Marine Mangrove-Fringed Creeks. Frontiers in Marine Science 7:1-11. https://doi.org/10.3389/fmars.2020.00696

Kaladharan P, Vijayakumaran K, Edward LL, et al (2021) Blue Carbon Stock of Seagrass Meadows of Chilika and Pulicat Lakes along the Eastern Coast of India

Kaladharan P, Zacharia PU, Thirumalaiselvan S, et al (2020) Blue carbon stock of the Seagrass meadows of gulf of Mannar and Palk bay off Coromandel coast, south India. Indian Journal of Fisheries 67:149-153. https://doi.org/10.21077/ijf.2020.67.4.98101-18

Kennedy H, Beggins J, Duarte CM, et al (2010) Seagrass sediments as a global carbon sink: Isotopic constraints. Global Biogeochemical Cycles 24:1-8. https://doi.org/10.1029/2010GB003848

Koshy NE, Bhatt JR, Vakily JM (2018) Synthesis of the Conference on Management and Conservation of Seagrass Ecosystems in India. Ocean and Coastal Management 159:36. https://doi.org/10.1016/j.ocecoaman.2017.11.001

Karstensen, J., Roy, J., Deb Pal, B., Peters, G., Andrew, R., 2020. Key drivers of Indian greenhouse gas emissions. Econ. Polit. Wkly. 55, 46-53.

Lavery PS, Mateo MÁ, Serrano O, Rozaimi M (2013) Variability in the Carbon Storage of Seagrass Habitats and Its Implications for Global Estimates of Blue Carbon Ecosystem Service. PLoS ONE 8:. https://doi.org/10.1371/journal.pone.0073748

Liu S, Trevathan-Tackett SM, Ewers Lewis CJ, et al (2020) Macroalgal Blooms Trigger the Breakdown of Seagrass Blue Carbon. Environmental Science and Technology. https://doi.org/10.1021/acs.est.0c03720

M. Stankovic, R. Ambo-Rappe, F. Carly et al. (2021) Quantification ofblue carbon in seagrass ecosystems ofSoutheast Asia and their potential for climate change mitigation. Science of The Total Environment 146858:. https://doi.org/10.1016/j.scitotenv.2021.146858 
56Mazarrasa I, Samper-Villarreal J, Serrano O, et al (2018) Habitat characteristics provide insights

\section{1 https://doi.org/10.1016/j.marpolbul.2018.01.059}

57Mishra AK, Kumar M (2020) Andaman mangrove sediments : source of nutrients and sink of 573 heavy metals. Indian Journal of Geo Marine Sciences 49:156-166.

574 https://doi.org/10.1101/431262

57Mishra AK, Mohanraju R (2018) Epiphytic Bacterial Communities in Seagrass Meadows of 576 Oligotrophic Waters of Andaman Sea. OALib 05:1-12.

577 https://doi.org/10.4236/oalib.1104388

578 Mishra, A., Apte, D., 2020. Ecological connectivity with mangroves influences tropical 579 seagrass population longevity and meadow traits within an island ecosystem. Mar. Ecol. 580 Prog. Ser. 644, 47-63. https://doi.org/10.3354/meps 13349

Mishra, A.K., Khadanga, M.K., Patro, S., Apte, D., Hilal, S., 2021a. Population structure of a newly recorded ( Halodule uninervis ) and native seagrass ( Halophila ovalis ) species from an intertidal creek ecosystem. Lakes Reserv. Res. Manag. 1-12. https://doi.org/10.1111/lre.12376

Mishra, A.K., Narayana, S., Apte, D., 2021b. Loss of Dugong Grass [Halophila Ovalis (R. Brown)] Population Structure Due to Habitat Disturbance in an Island Ecosystem. Indian J. Geo-Marine Sci. 50, 115-121.

Miyajima T, Hori M, Hamaguchi M, et al (2017) Geophysical constraints for organic carbon sequestration capacity of Zostera marina seagrass meadows and surrounding habitats. Limnology and Oceanography 62:954-972. https://doi.org/10.1002/1no.10478

Nobi EP, Dilipan E, Thangaradjou T, et al (2010) Geochemical and geo-statistical assessment of heavy metal concentration in the sediments of different coastal ecosystems of 

Andaman Islands, India. Estuarine, Coastal and Shelf Science 87:253-264. https://doi.org/10.1016/j.ecss.2009.12.019

Nordhaus WD (2017) Revisiting the social cost of carbon. Proceedings of the National Academy of Sciences of the United States of America 114:1518-1523. https://doi.org/10.1073/pnas.1609244114

Potouroglou M, Bull JC, Krauss KW, et al (2017) Measuring the role of seagrasses in regulating sediment surface elevation. Scientific Reports 7:1-11. https://doi.org/10.1038/s41598-017-12354-y

Potouroglou M, Whitlock D, Milatovic L, et al (2021) The sediment carbon stocks of intertidal seagrass meadows in Scotland. Estuarine, Coastal and Shelf Science 258:107442. https://doi.org/10.1016/j.ecss.2021.107442

Ragavan P, Jayaraj R, Muruganantham M, Jeeva C (2016) Species Composition and Distribution of Sea grasses of The Andaman and Nicobar Islands

Ramesh R, Banerjee K, Paneer Selvam A, et al (2018) Legislation and policy options for conservation and management of seagrass ecosystems in India. Ocean and Coastal Management 159:46-50. https://doi.org/10.1016/j.ocecoaman.2017.12.025

Ricart AM, York PH, Bryant C V, Rasheed MA (2020) High variability of Blue Carbon storage in seagrass meadows at the estuary scale. Scientific Reports. https://doi.org/10.1038/s41598-020-62639-y

Ricart AM, York PH, Rasheed MA, et al (2015) Variability of sedimentary organic carbon in patchy seagrass landscapes. Marine Pollution Bulletin 100:476-482. https://doi.org/10.1016/j.marpolbul.2015.09.032

Ricke K, Drouet L, Caldeira K, Tavoni M (2018) Country-level social cost of carbon. Nature Climate Change 8:895-900. https://doi.org/10.1038/s41558-018-0282-y

Saenger, P., Gartside, D., \& Funge-Smith S 2012. (2012) A review of mangrove and seagrass ecosystems and their linkage to

Sahu BK, Begum M, Khadanga MK, et al (2013) Evaluation of significant sources influencing the variation of physico-chemical parameters in Port Blair Bay, South Andaman, India by using multivariate statistics. Marine Pollution Bulletin 66:246-251. https://doi.org/10.1016/j.marpolbul.2012.09.021 
623 Salinas C, Duarte CM, Arias-ortiz A, et al (2020) Seagrass losses since mid-20th century

624

625

626

627

628

629

630

631

632

633

634

635

636

637

638

639

640

641

642

643

644

645

646

647

648

649

650 fuelled CO 2 emissions from soil carbon stocks. 1-13. https://doi.org/10.1111/gcb.15204

Samper-Villarreal J, Lovelock CE, Saunders MI, et al (2016) Organic carbon in seagrass sediments is influenced by seagrass canopy complexity, turbidity, wave height, and water depth. Limnology and Oceanography 61:938-952. https://doi.org/10.1002/lno.10262

Santos IR, Burdige DJ, Jennerjahn TC, et al (2021) The renaissance of Odum's outwelling hypothesis in "Blue Carbon" science. Estuarine, Coastal and Shelf Science 255:107361. https://doi.org/10.1016/j.ecss.2021.107361

Savurirajan M, Equbal J, Lakra RK, et al (2018) Species diversity and distribution of seagrasses from the South Andaman, Andaman and Nicobar Islands, India. Botanica Marina 61:225-234. https://doi.org/10.1515/bot-2017-0109

Serrano O, Almahasheer H, Duarte CM, Irigoien X (2018) Carbon stocks and accumulation rates in Red Sea seagrass meadows. Scientific Reports 8:1-13. https://doi.org/10.1038/s41598-018-33182-8

Serrano O, Lavery PS, Bongiovanni J, Duarte CM (2020) Impact of seagrass establishment, industrialization and coastal infrastructure on seagrass biogeochemical sinks. Marine Environmental Research 160:104990. https://doi.org/10.1016/j.marenvres.2020.104990

Singh G, Ganguly D, Selvam AP, et al (2015) Seagrass Ecosystem and Climate Change: An Indian Perspective. Journal of Climate Change 1:67-74. https://doi.org/10.3233/JCC150005

Stankovic M, Ambo-Rappe R, Carly F, et al (2021) Quantification of blue carbon in seagrass ecosystems of Southeast Asia and their potential for climate change mitigation. Science of The Total Environment 783:146858. https://doi.org/10.1016/j.scitotenv.2021.146858

UNEP (2020) Protecting Seagrass Through Payments for Ecosystem Services: A Community Guide 


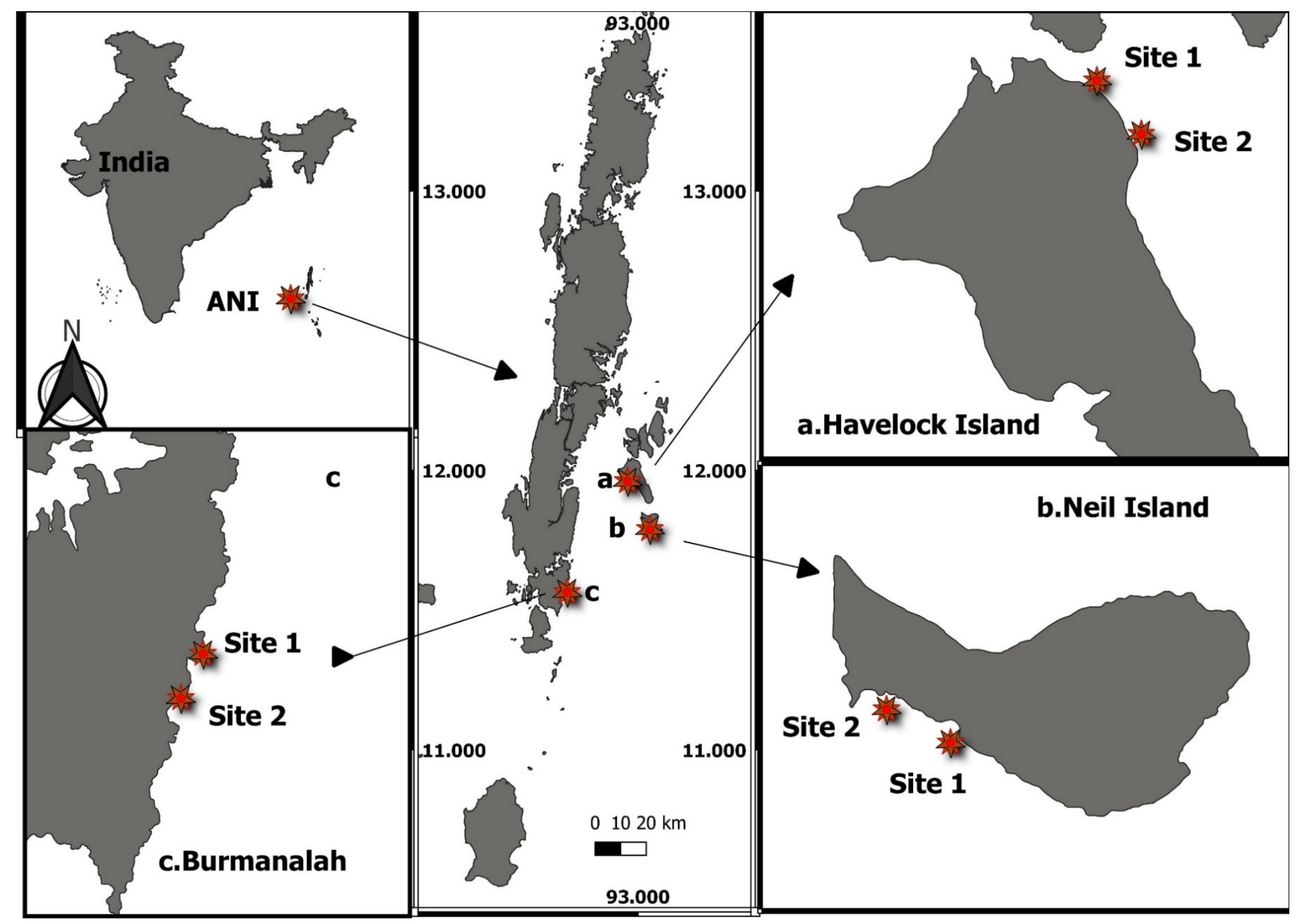


Fig.1. Map showing the study locations of a) Havelock Island, b) Neil Island and c) Burmanallah of ANI, India. Seagrass areas with mangroves

652 are presented as Site 1 and without mangroves as Site 2

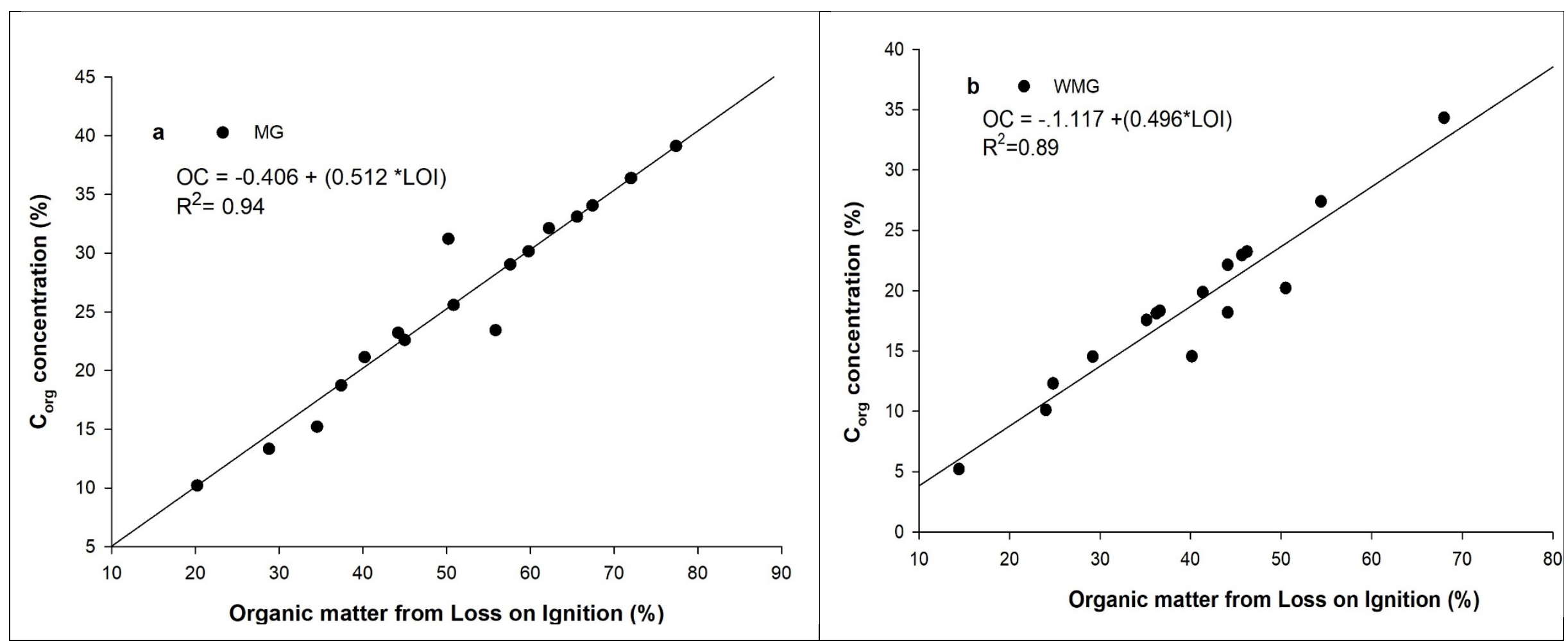

Fig. 2 The relationship of organic matter (\%LOI) with organic carbon (\%OC) for the seagrass ecosystems with mangroves (a) and without 654 mangroves (b) of ANI, India. 


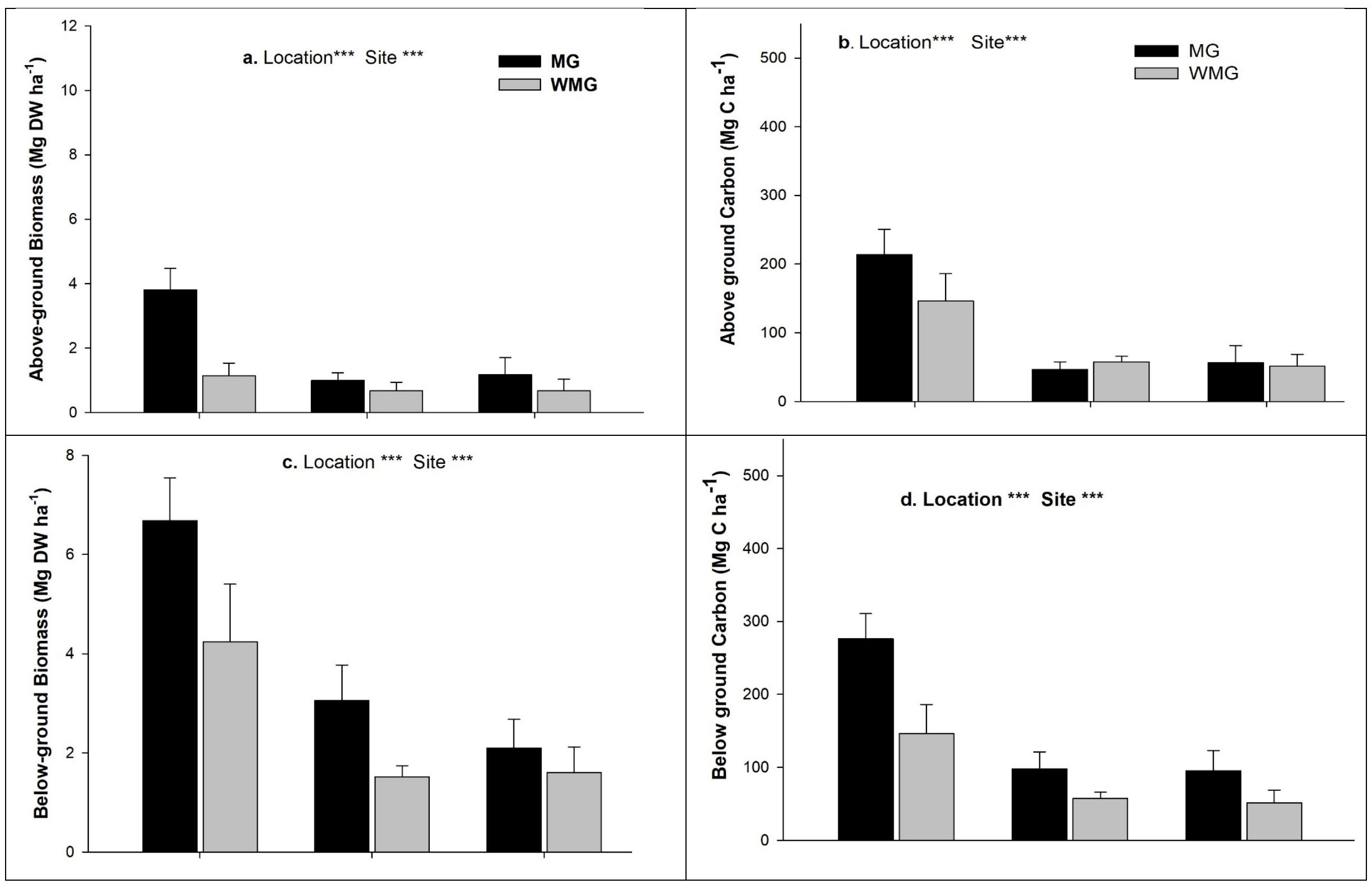




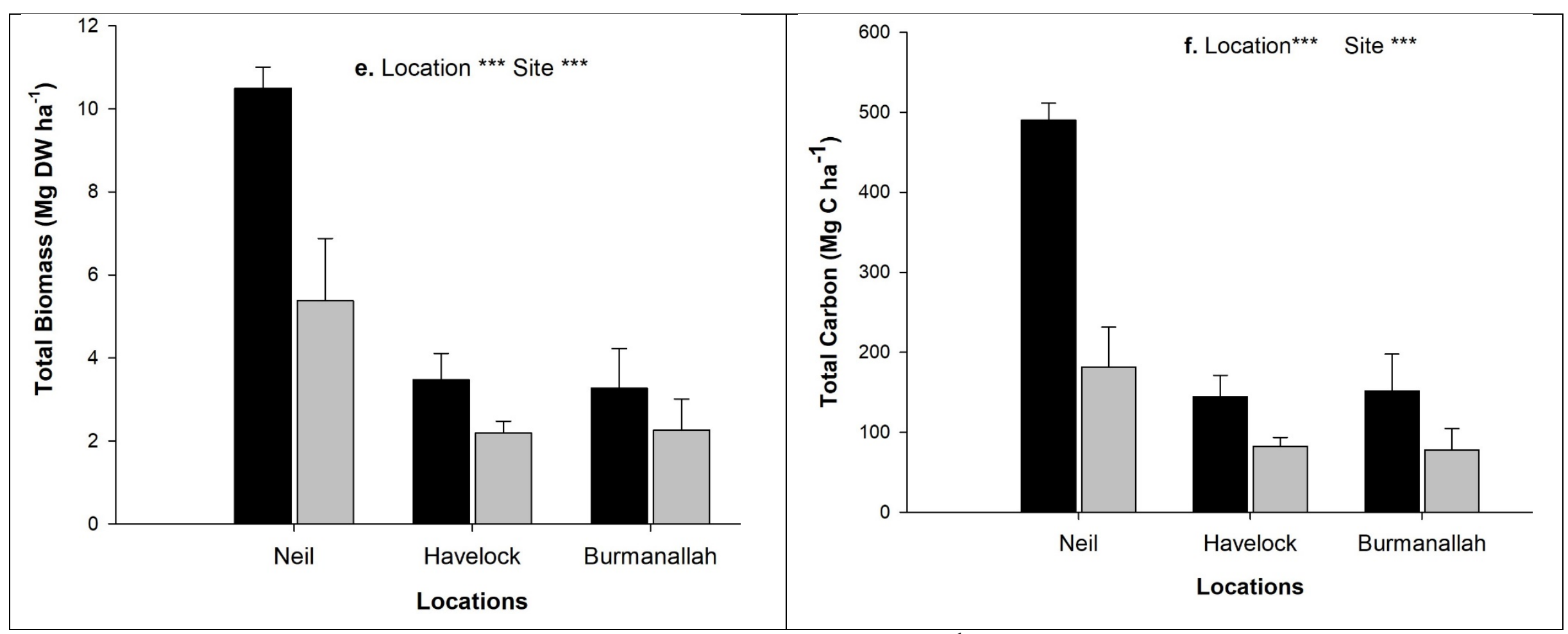

Fig. 3. Average values (mean $\pm \mathrm{SD})$ of biomass (Mg DW ha-1) and the carbon (Mg C ha $\left.{ }^{-1}\right)$ stored in the respective biomass of T. hemprichii in the sites with and without mangroves of Neil, Havelock and Burmanallah location of ANI, India. Significant differences were derived from two-way ANOVA analysis using location and site as fixed factors. $(p<0.001 * * *, \mathrm{p}<0.01 * *)$. 


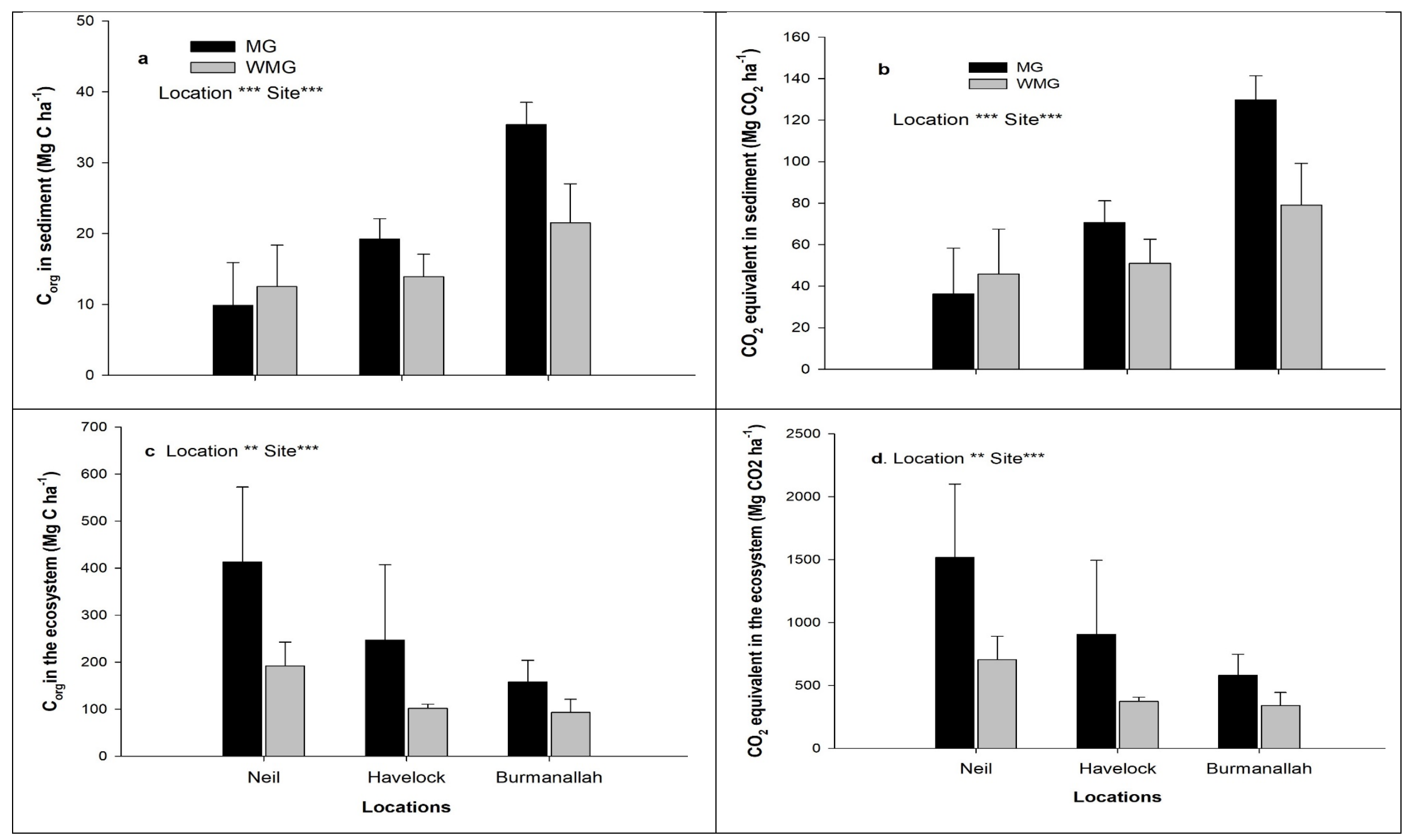


Fig.4. Average values (mean $\pm \mathrm{SD}$ ) of the carbon $\left(\mathrm{Mg} \mathrm{C} \mathrm{ha}^{-1}\right)$ stored in the sediment and seagrass ecosystem (sediment + seagrass biomass) and their $\mathrm{CO}_{2}$ equivalent of $T$. hemprichii meadows in the sites with and without mangroves of Neil, Havelock and Burmanallah location of ANI, India. Significant differences were derived from two-way ANOVA analysis using location and site as fixed factors. $(p<0.001 * * *, \mathrm{p}<0.01 * *)$.
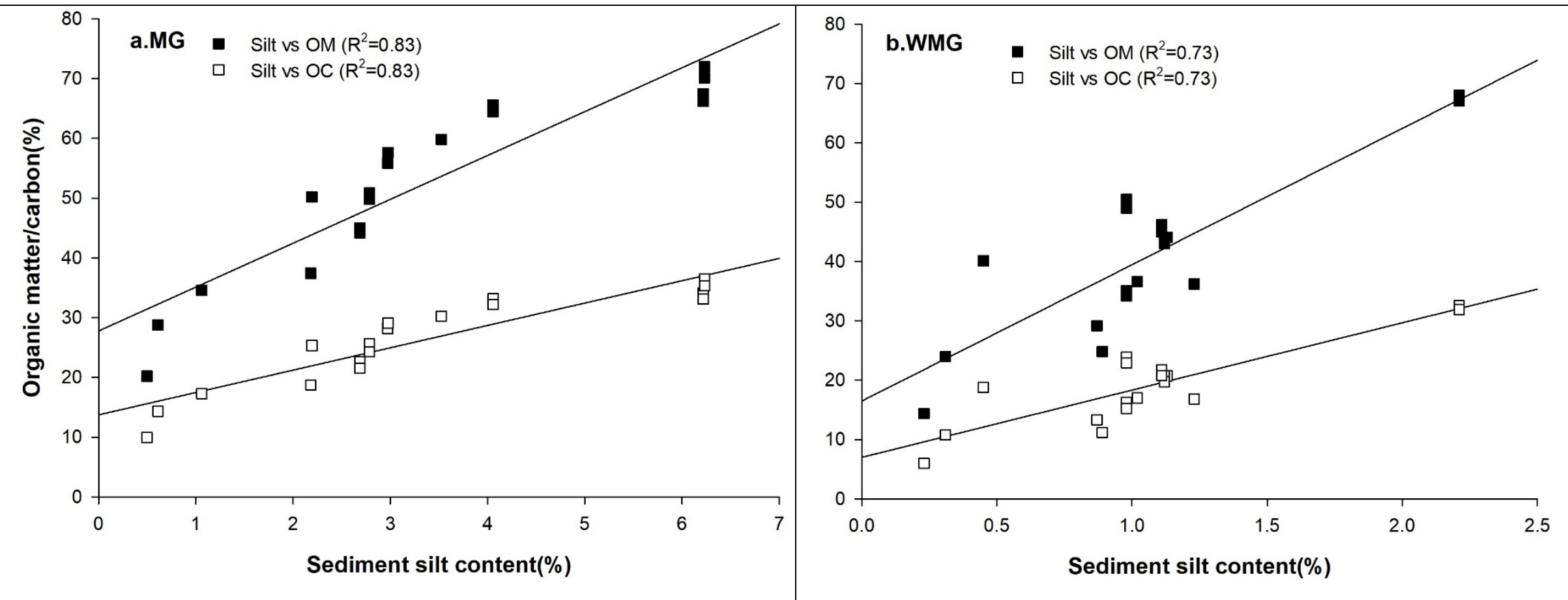

Fig.5. Relationship between sediment silt (\%) and organic matter/carbon (\%) content in the seagrass meadows of ANI, India a) with mangroves (MG) and b) without mangroves (WMG). $\mathrm{R}^{2}$ values derived from linear regression are provided. 


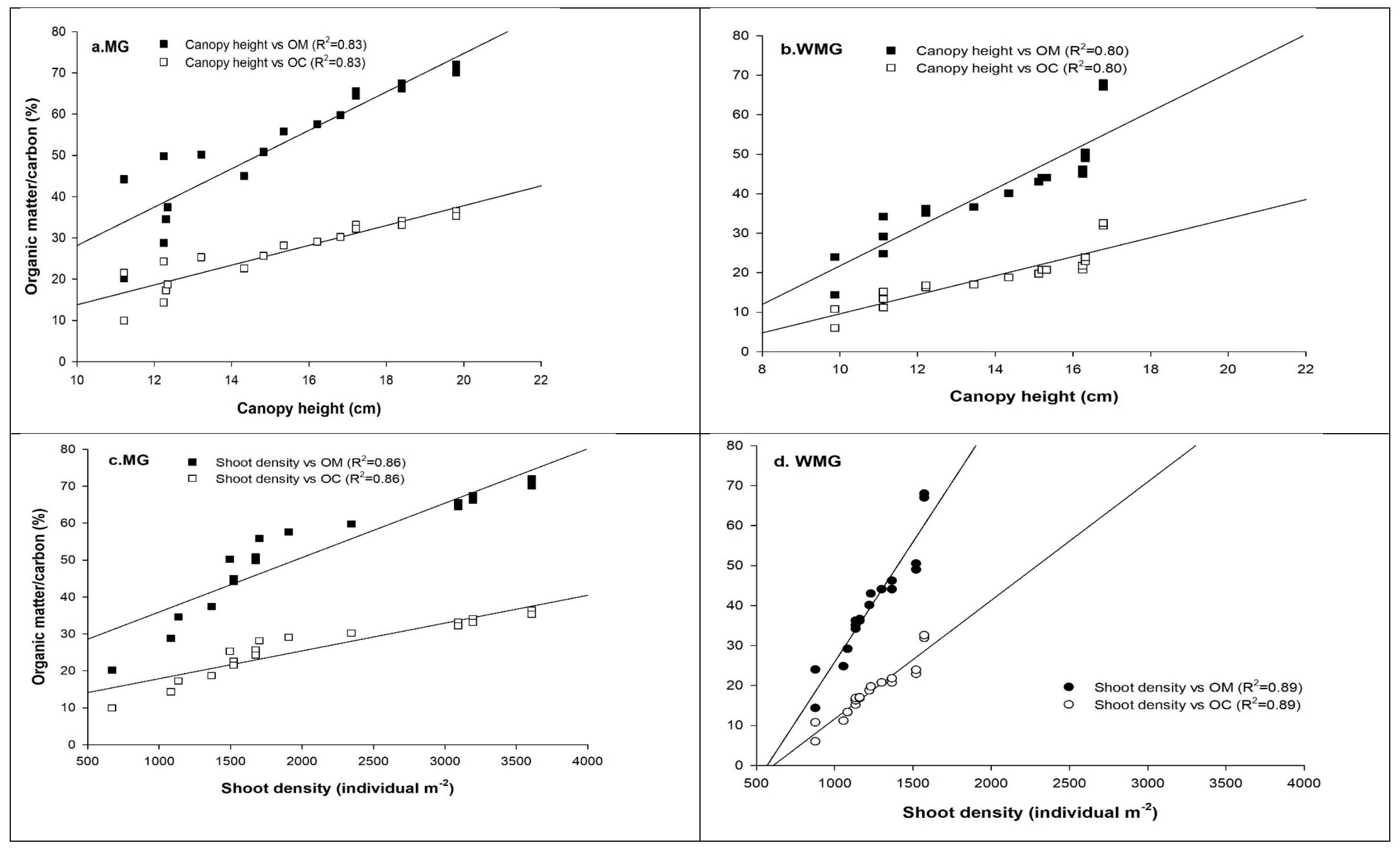


Fig.6. Relationship between the seagrass canopy height $(\mathrm{cm})$ and shoot density (individual $\mathrm{m}^{-2}$ ) with organic matter/carbon (\%) content in the seagrass meadows of ANI, India a \& c) with mangroves (MG) and b \& d) without mangroves (WMG). $\mathrm{R}^{2}$ values derived from linear regression 670 are provided.

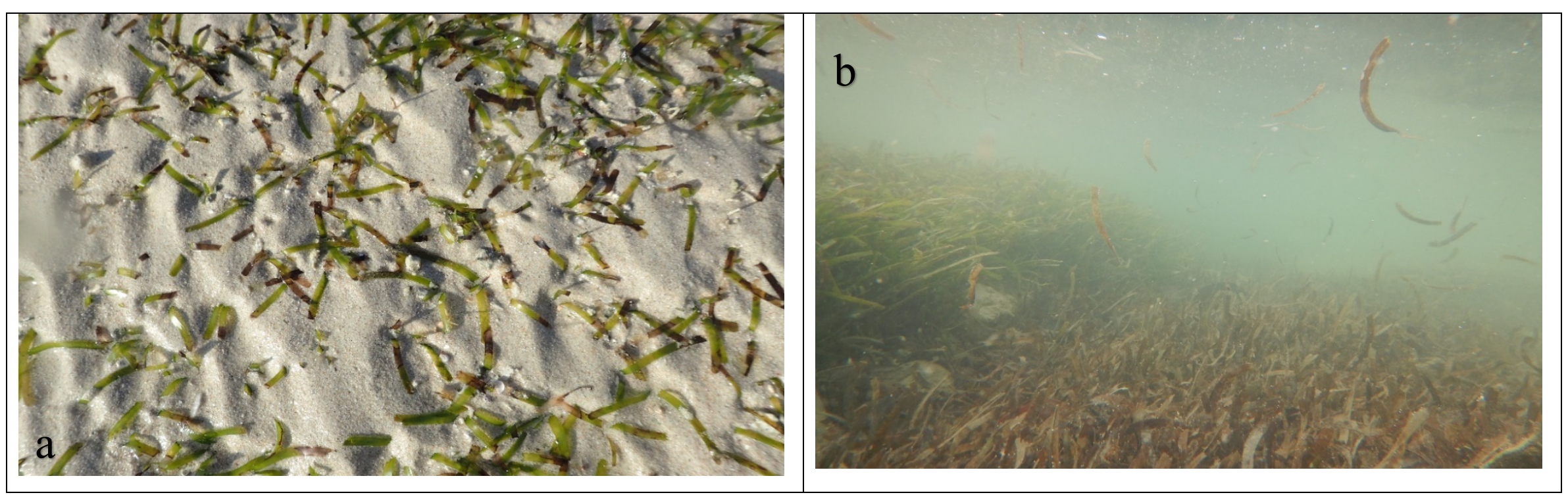




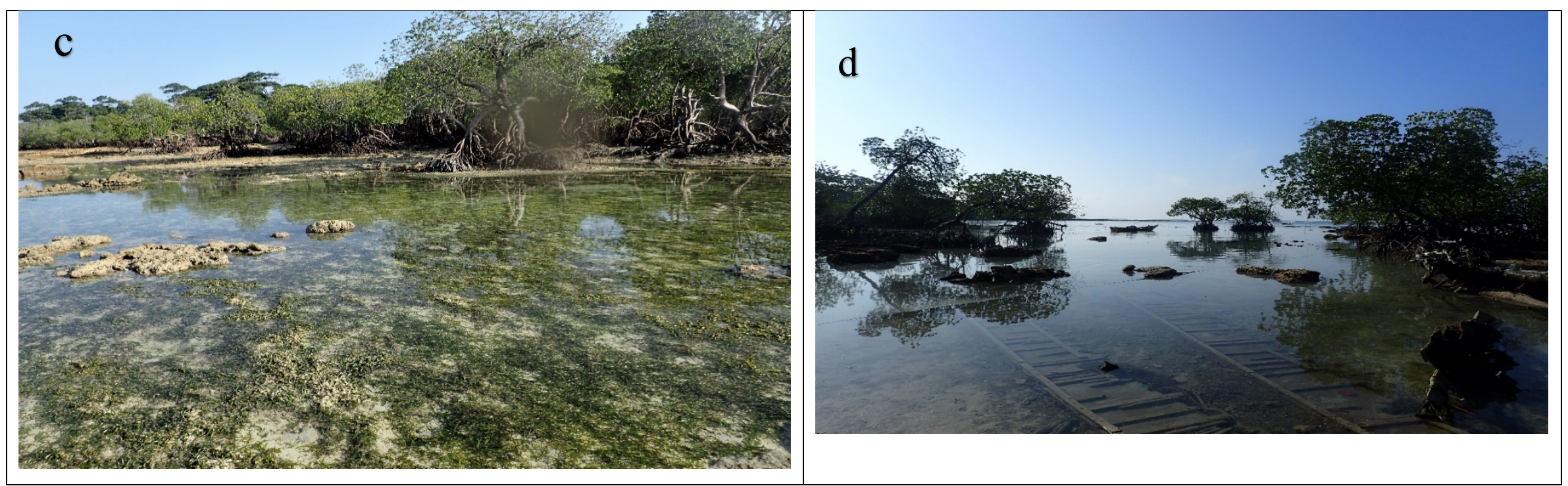

Fig.7. Pictures of Thalassia hemprichii meadows with a) leaf reddening and b) breakage of leaves during tidal inundation at WMG sites, and c) 672 sheltered at mangrove sites during low tide and d) associated with mangrove ecosystems of Neil Islands.

673 Table 1. Summary of data for seagrass biomass and soil properties from the seagrass areas with mangroves (MG) and without mangroves (WMG) 674 of ANI, India. Range and mean \pm standard deviation (SD) is presented. The social cost of carbon was adopted as US\$86 (=6395.07 INR) per tonne of $\mathrm{CO}_{2}$.

\begin{tabular}{|l|l|l|l|l|}
\hline Seagrass/Variables & Range & & Mean \pm SD \\
\hline & MG & WMG & MG & WMG \\
\hline Sediment dry bulk density $\left(\mathrm{g} \mathrm{cm}^{-3}\right)$ & $0.18-1.11$ & $0.64-1.09$ & $0.75 \pm 0.23$ & $0.84 \pm 0.13$ \\
\hline Sediment organic matter $(\%$ dry weight) & $20.21-72.03$ & $14.5-68$ & $52.55 \pm 16.49$ & $39.56 \pm 13.39$ \\
\hline Sediment $C_{\text {org }}(\%$ dry weight) & $9.47-36.49$ & $6.01-32.58$ & $26.51 \pm 8.44$ & $18.49 \pm 6.63$ \\
\hline
\end{tabular}




\begin{tabular}{|c|c|c|c|c|}
\hline Carbon content in above-ground biomass $(\% \mathrm{C})$ & $30.63-79.53$ & $25.70-39.38$ & $49.12 \pm 17.12$ & $35.10 \pm 5.33$ \\
\hline Carbon content in below-ground biomass $(\% \mathrm{C})$ & $19.42-68.12$ & $28.72-44.09$ & $43.73 \pm 12.26$ & $34.87 \pm 5.27$ \\
\hline Above-ground biomass $\left(\mathrm{Mg} \mathrm{C} \mathrm{ha}^{-1}\right)$ & $22.89-263.67$ & $9.34-50.73$ & $90.78 \pm 70.7$ & $27.74 \pm 11.91$ \\
\hline Below-ground biomass $\left(\mathrm{Mg} \mathrm{C} \mathrm{ha}^{-1}\right)$ & $52.37-301.26$ & $22.95-187.52$ & $141.89 \pm 83.7$ & $78.23 \pm 45.38$ \\
\hline Total biomass ( $\left.\mathrm{Mg} \mathrm{C} \mathrm{ha}^{-1}\right)$ & $86.54-526.70$ & $34.83-224.51$ & $232.68 \pm 155$ & $105.98 \pm 52.42$ \\
\hline Carbon content in the sediment $\left(\mathrm{Mg} \mathrm{C} \mathrm{ha}^{-1}\right)$ & $1.79-39.59$ & $3.90-29.65$ & $21.87 \pm 11.53$ & $15.62 \pm 6.50$ \\
\hline $\begin{array}{l}\text { Total Carbon in the sediment }(\mathrm{Mg} \mathrm{C}) \text { in total area, } \\
\text { MG (144 ha); WMG (148 ha) }\end{array}$ & $40.28-2883$ & $7.80-1779$ & $1265.35 \pm 1010$ & $839.07 \pm 641.05$ \\
\hline $\begin{array}{l}\mathrm{CO}_{2} \text { equivalent storage in sediment }(\mathrm{Mg} \mathrm{CO}) \text { in total } \\
\text { area, } \\
\text { MG (144 ha); WMG (148 ha) }\end{array}$ & $147-10400$ & $28.65-6529$ & $4643.75 \pm 3709$ & $3079.41 \pm 2352$ \\
\hline $\begin{array}{l}\text { Price in US\$ and INR (Values expressed in million, i.e., } \\
10^{6} \text { ) }\end{array}$ & $\begin{array}{l}0.012-0.89(\$) \\
0.94-66.51(\mathrm{INR})\end{array}$ & $\begin{array}{l}0.002-0.56(\$) \\
0.18-41.75 \\
(\mathrm{INR})\end{array}$ & $\begin{array}{l}0.39 \pm 0.31(\$) \\
29.69 \pm 23.72(\mathrm{INR})\end{array}$ & $\begin{array}{l}0.26 \pm 0.20(\$) \\
19.69 \pm 15.05 \\
(\text { INR })\end{array}$ \\
\hline Carbon in the ecosystem $\left(\mathrm{Mg} \mathrm{C} \mathrm{ha}^{-1}\right)$ & $93.02-530.78$ & $48.79-240$ & $272.54 \pm 164$ & $128.79 \pm 55.89$ \\
\hline $\begin{array}{l}\text { Total carbon in the ecosystem }(\mathrm{Mg} \mathrm{C}) \text { in total area, } \\
\text { MG (144 ha); WMG (148 ha) }\end{array}$ & $2885-26751$ & $226-9646$ & $11031 \pm 5223$ & $4921 \pm 3725$ \\
\hline $\begin{array}{l}\mathrm{CO}_{2} \text { equivalent storage in the ecosystem }\left(\mathrm{Mg} \mathrm{CO}_{2}\right) ; \mathrm{MG} \\
(144 \mathrm{ha}) ; \mathrm{WMG}(148 \mathrm{ha})\end{array}$ & $10591.46-98177$ & $830-35402$ & $40487 \pm 19171$ & $18036 \pm 13672$ \\
\hline $\begin{array}{l}\text { Price in US\$ and INR (Values expressed in million, i.e., } \\
10^{6} \text { ) }\end{array}$ & $\begin{array}{l}9.11-84.3(\$) \\
677-6278(\mathrm{INR})\end{array}$ & $\begin{array}{l}0.07-3.04(\$) \\
5.31-226(\mathrm{INR})\end{array}$ & $\begin{array}{l}34.82 \pm 16.48(\$) \\
2589 \pm 1226(\mathrm{INR})\end{array}$ & $\begin{array}{l}1.55 \pm 1.17(\$) \\
115.52 \pm 87(\mathrm{INR})\end{array}$ \\
\hline
\end{tabular}


677 Table 2. Mean \pm SD values are presented from literature review for various blue carbon studies in India using different seagrass species and the 678 data from present study of T. hemprichii meadows with mangroves (MG) and without mangroves (WMG) of ANI.

\begin{tabular}{|c|c|c|c|c|}
\hline Location & Species & $\begin{array}{ll}\text { Corg } & (\% D W) i n \\
\text { sediment } & \end{array}$ & $\begin{array}{l}\text { Blue carbon stock (Mg C } \\
\left.\text { ha }^{-1}\right)\end{array}$ & Reference \\
\hline Chilika lake, Odisha & Mixed seagrass & 0.395 & $2.018 \pm 0.67$ & (Kaladharan et al., 2021) \\
\hline Pulicat lake, Tamil Nadu & Mixed seagrass & 0.473 & $0.998 \pm 0.41$ & Kaladharan et al., 2021 \\
\hline Gulf of Mannar, Tamil Nadu & Mixed seagrass & $0.09 \pm 0.014$ & 3.45 & (Kaladharan et al., 2020) \\
\hline Palk Bay, Tamil Nadu & Mixed seagrass & $0.71 \pm 0.08$ & 3.88 & “" \\
\hline \multirow[t]{3}{*}{ Gulf of Mannar, Tamil Nadu } & C. serrulata & 1.98 & - & Ghosh et al., 2016 \\
\hline & H. ovalis & 1.13 & - & 66 \\
\hline & T. hemprichii & 1.07 & - & “" \\
\hline Chilika lake, Odisha & $\begin{array}{l}\text { H. ovalis }+H . \\
\text { uninervis }\end{array}$ & $0.68-0.93$ & 127.08 & (Ganguly et al., 2017) \\
\hline Palk Bay, Tamil Nadu & $\begin{array}{lr}\text { C. serrulata } & +T . \\
\text { hemprichii } & +S . \\
\text { isoetifolium } & \end{array}$ & $0.97-1.01$ & 159.53 & “" \\
\hline Palk Bay, Tamil Nadu & $\begin{array}{l}\text { C. serrulata+ } S . \\
\text { isoetifolium }\end{array}$ & $0.93-1.01$ & & \\
\hline Andaman and Nicobar Islands & T. hemprichii (MG) & $26.51 \pm 8.44$ & $272.54 \pm 164$ & Present study \\
\hline
\end{tabular}




\begin{tabular}{|l|l|l|l|l|}
\hline & $\begin{array}{l}\text { T. hemprichii } \\
\text { (WMG) }\end{array}$ & $18.49 \pm 6.63$ & $128.79 \pm 55.89$ & 6 \\
\hline
\end{tabular}


